\title{
ANTIBACTERIAL ACTIVITY AND TLC-BIOAUTOGRAPHY ANALYSIS OF THE ACTIVE FRACTIONS OF Muntingia calabura L. LEAVES AGAINST Staphylococcus aureus
}

\author{
Rizky H. Mawardi, Nanik Sulistyani*), Nurkhasanah, Ricke Desyratnaputri
}

\author{
Faculty of Pharmacy, Universitas Ahmad Dahlan, Campus 3 Janturan, Warungboto, Umbulharjo, \\ Yogyakarta 55164, Indonesia
}

Received January 15, 2020; Accepted March 17, 2020

\begin{abstract}
This study aims to determine the antibacterial activity and TLC-bioautography profile of the active fractions of Muntingia calabura L. leaves against Staphylococcus aureus. Muntingia calabura L. leaves were macerated with ethanol $96 \%$ then fractionated with n-hexane, ethyl acetate, and methanol solvent, respectively. The antibacterial activity was tested by the KirbyBauer method to determine the most active fraction and the lowest concentration that inhibited the growth of Staphylococcus aureus. TLC-bioautography was tested using chloroform: ethyl acetate (2:8) as the mobile phase and silica gel $\mathrm{F}_{254}$ as the stationary phase. Antibacterial activity test of $\mathrm{n}$ hexane and ethyl acetate fractions at a concentration of $10 \% \mathrm{w} / \mathrm{v}$ showed activities with inhibition zone diameter of $0.33 \pm 0.288$ and $9.66 \pm 5.77 \mathrm{~mm}$, respectively. At the same time, the methanol fraction showed no activity. The lowest concentration of ethyl acetate fraction which still showed the inhibition zone was $0.312 \% \mathrm{w} / \mathrm{v}$. The TLC-bioautography profile showed active spots with an Rf value of 0.82 and had an inhibitory zone diameter of $4.013 \pm 0.864 \mathrm{~mm}$. It can be concluded that the ethyl acetate fraction was the most active fraction that inhibited the growth of Staphylococcus aureus and had one active spot on the bioautography test.
\end{abstract}

Keywords: antibacterial; Muntingia calabura L. leaf; Staphylococcus aureus; TLCbioautography.

\section{INTRODUCTION}

Staphylococcus aureus is a commensal bacteria in human skin and mucosae but this bacteria often causes serious infections with high morbidity and mortality (Sakr et al., 2018). Besides being frequently associated with skin and soft tissue infections, Staphylococcus aureus can also cause a variety of serious invasive infections such as osteomyelitis, necrotizing pneumonia, and bacteremia (Williamson et al., 2013). Staphylococcus aureus is a serious problem because of the increased resistance of these bacteria to various types of antibiotics (MultiDrug Resistance). Staphylococcus aureus has unique adaptability so that it can be resistant to many antibiotics (Afifurrahman et al., 2014).
Therefore, it is necessary to explore new antibacterial compounds from various sources such as medicinal plants.

Muntingia calabura L. leaves have been shown to have antibacterial activity against both Gram-positive and Gram-negative bacteria (Arum et al., 2012; Handoko et al., 2019). Arum et al. (2012) reported that ethanol and methanol extracts of Muntingia calabura L. leaves have antibacterial activity against Escherichia coli, Pseudomonas aeruginosa, Bacillus subtilis, and Staphylococcus aureus. Research done by Manik et al. (2014) showed that ethanol extract of Muntingia calabura L. leaves has antibacterial activity against Staphylococcus 
aureus where the Minimum Bactericidal Concentration (MBC) value of ethanol extract is $1.25 \mathrm{mg} / \mathrm{mL}$. The antibacterial activity of Muntingia calabura L. leaves is presumed to exist because it contains bioactive compositions such as flavonoids, tannins, and saponins (Zebua et al., 2019).

The extract still contains a mixture of various compounds so that fractionation is needed to attract the active compound based on their polarity level. One way to detect the active compounds is by using the TLCbioautography method. TLC-bioautography can show spots from Thin Layer Chromatography (TLC) that can inhibit bacterial growth (Muthadi et al., 2012). This study aims to determine the antibacterial activity and TLC-Bioautographic profile of the active fractions of Muntingia calabura L. leaves against Staphylococcus aureus.

\section{METHODS}

\section{Materials and Chemicals}

Muntingia calabura L. leaves were collected from Sleman, Yogyakarta, Indonesia. Staphylococcus aureus isolates were collected from Center for Health Laboratory Yogyakarta. The other materials and chemicals used were Brain Heart Infusion (Oxoid), Mueller Hinton Agar (Oxoid) $\mathrm{NaCl}$ $0.9 \%$ (sterile), Mc Farland 0.5 (concentration $1.5 \times 10^{8} \mathrm{CFU} / \mathrm{mL}$ ), ethanol $96 \%$, n-hexane, ethyl acetate, methanol, paper disk (Oxoid), and TLC silica gel $F_{254}$ (Merck).

\section{Extraction and Fractionation}

Muntingia calabura L. leaves were dried using an oven at $45^{\circ} \mathrm{C}$ for four days then mashed by blending. The dry powder obtained was extracted by employing the maceration method. The dry powder of Muntingia calabura L. leaves $(500 \mathrm{~g})$ was extracted with $4000 \mathrm{~mL}$ ethanol $96 \%$ (1:8), stirred using a stirrer for 3 hours and then stored in 24 hours. Next, the macerated substance was filtered and concentrated using a rotary evaporator (Sulaiman et al., 2017). The extract obtained was then suspended in warm water and fractionated with n-hexane, ethyl acetate, and methanol solvent, respectively using the liquid-liquid partitioning method (Mulyani and Sukandar, 2011).

\section{Media Preparation}

Brain Heart Infusion (BHI) media was prepared by dissolving $3.7 \mathrm{~g}$ of $\mathrm{BHI}$ powder in $100 \mathrm{~mL}$ of distilled water while being heated and stirred until homogeneous. BHI media was sterilized using an autoclave at $121{ }^{\circ} \mathrm{C}$ for 15 minutes (Lolongan et al., 2016).

Mueller Hinton Agar (MHA) media was prepared by dissolving $19 \mathrm{~g}$ of MHA powder in $500 \mathrm{~mL}$ distilled water while being heated and stirred until homogeneous. The media was sterilized using an autoclave at $121^{\circ} \mathrm{C}$ for 15 minutes and then put in a $20 \mathrm{~mL}$ petri dish and allowed to harden (Mahmudah et al., 2017).

\section{Bacterial Preparation}

A total of $1 \mathrm{~mL}$ of Staphylococcus aureus stock was put into $1 \mathrm{~mL}$ of BHI media and incubated at $37^{\circ} \mathrm{C}$ for 24 hours. The bacteria culture was then taken for as much as $100 \mu \mathrm{L}$, put into $1 \mathrm{~mL}$ of BHI media, and incubated at $37^{\circ} \mathrm{C}$ for $3-5$ hours. The bacterial culture was then taken for as much as $100 \mu \mathrm{L}$ and was diluted using $0.9 \% \mathrm{NaCl}$ sterile until the turbidity was the same as the Mc Farland 0.5 standard $\left(1.5 \times 10^{8} \mathrm{CFU} / \mathrm{mL}\right)$.

\section{Antibacterial Activity Test}

The determination of the active fraction was carried out using the Kirby-Bauer method. A total of $20 \mu \mathrm{L}$ of extract and fractions with a concentration of $10 \% \mathrm{w} / \mathrm{v}$ each were dripped on a $6 \mathrm{~mm}$ disc paper. The disc paper was then transferred aseptically to the MHA media that had been planted with test bacteria and then incubated using an incubator at $37^{\circ} \mathrm{C}$ for 24 hours. The most active fraction is the one that has the largest inhibitory zone (Sylvester et al., 2015). The lowest concentration of the most active fraction that inhibited Staphylococcus aureus was determined using the same method. The most active fractions with concentrations of $10 \%, 5 \%, 2.5 \%, 1.25 \%$, $0.625 \%, 0.312$ and $0.156 \%$ were tested using the Kirby-Bauer method. 


\section{TLC-Bioautography}

The test to find out the most active fraction was carried out by TLC method using chloroform:ethyl acetate $(2: 8)$ as the mobile phase and silica gel $\mathrm{F}_{254}$ as the stationary phase. After elution, spots on the TLC plate were then observed under visible light and UV light with wavelengths of 254 and $366 \mathrm{~nm}$. Furthermore, the chromatogram plate was contacted with the surface of MHA media which had been inoculated by Staphylococcus aureus for 30 minutes. The plate was removed and the culture was incubated at $37^{\circ} \mathrm{C}$ for 24 hours (Muthadi et al., 2012).

\section{Statistical Analysis}

Inhibition zone data in the minimum inhibitory test were tested for their normality and homogeneity. The normality test was done using the Kolmogorov-Smirnov and Lilliefors, while the homogeneity test was done using One Way ANOVA and LSD with a confidence level of $95 \%$. If the distribution is normal and homogeneous, then the correlation test will be done using the Pearson test. If the data are not normally distributed and are not homogeneous, further tests need to be performed using the Kruskal-Wallis and Mann-Whitney while the correlation test is performed using the Spearman test.

\section{RESULTS AND DISCUSSION}

In this study, Muntingia calabura L. leaves were extracted using the maceration method which obtained $19.07 \%$ extract yield. A non-heating extraction method was chosen to avoid damaging heat-resistant compounds that might be contained in the sample. Immersion of Muntingia calabura L. leaves in the solvent can make the compounds contained in cells soluble, and because of the differences in concentration between the solution of compounds inside and outside the cell, the compounds from high concentrations in the cell will diffuse out. In a previous study conducted by Puspitasari et al., (2016), Muntingia calabura L. leaves extraction using the maceration method obtained a yield of $26.58 \%$. Yield extraction results can be influenced by several factors, including biological factors and chemical factors. The biological factors include harvesting time, location of growth, plant species and plant parts used while the chemical factors include extraction methods, size, hardness, dryness of the material, type of solvent used, and types and levels of active compounds contained in plant material (Prastiwi et al., 2017).

The extract was fractionated successively using n-hexane, ethyl acetate and methanol solvents which aimed to separate the compounds based on their degree of polarity. The results of fractionation in this study showed that the yield of n-hexane, ethyl acetate, and methanol was $38.36 \%, 13.00 \%$, and $7.70 \%$, respectively. Non-polar compounds such as oil, carotenoids, steroids, and triterpenoids will tend to dissolve in nonpolar solvents such as n-hexane. Semi-polar compounds such as aglycone flavonoids will tend to dissolve in semi-polar solvents such as ethyl acetate. Polar compounds such as flavonoids glycosides will tend to dissolve in polar solvents, such as methanol, according to the principle of 'like dissolves like' (Suryanto, 2012).

The most active fraction that inhibited the growth of Staphylococcus aureus was determined through antibacterial activity testing of each fraction using the Kirby-Bauer method. As a comparison, ethanol extract, negative control (96\% ethanol) and positive control (Vancomycin Antimicrobial Susceptibility Disks $30 \mu \mathrm{g}$ ) were also tested. The results showed that the ethyl acetate fraction was the most active fraction associated with the formation of the largest inhibition zone diameter compared to the inhibition zone of the related fraction presented in (Figure 1). The inhibition zone of ethanol extract, n-hexane and ethyl acetate fractions in 3 replications were $3.33 \pm 0.577$, $0.33 \pm 0.288$ and $9.66 \pm 0.577 \mathrm{~mm}$ while the methanol fraction did not show inhibitory activity, as shown in (Table 1). The category of antibacterial activity can be distinguished based on its strength according to Rahmawati et al. (2014): if the diameter of antibacterial inhibition zone is more than $20 \mathrm{~mm}$, the activity is classified into very strong; if it is between $11-20 \mathrm{~mm}$, it is classified into 
moderate; and if it is less than $5 \mathrm{~mm}$, it is classified into weak. Based on this classification, the ethyl acetate which produced a clear zone of $9.66 \pm 0.577 \mathrm{~mm}$ was classified into medium category.

The lowest concentration of ethyl acetate fraction that still showed the zone of inhibition against Staphylococcus aureus was determined using the Kirby-Bauer disk diffusion method. The results showed that the ethyl acetate fraction could still inhibit the growth of Staphylococcus aureus bacteria at the lowest concentration of $0.312 \%$ (Figure 2) with the inhibition zone of $0.33 \pm 0.288$ (Table 2).

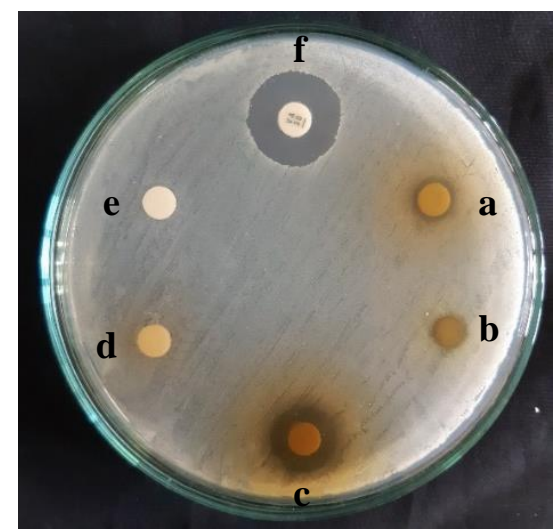

Figure 1. Screening of The Active Fractions; (a) $10 \%$ ethanol extract, (b) $10 \%$ n-hexane fraction, (c) $10 \%$ ethyl acetate fraction, (d) $10 \%$ methanol fraction, (e) negative control and (f) positive control.

Table 1. Inhibition zone diameters of the extract and fractions against Staphylococcus aureus.

\begin{tabular}{ccc}
\hline Extract and Fractions & $\begin{array}{c}\text { Inhibition Zone } \\
(\mathbf{m m})\end{array}$ & Category \\
\hline Ethanol Extract $(10 \% \mathrm{w} / \mathrm{v})$ & $3.33 \pm 0.577$ & Weak \\
\hline n-hexane Fraction $(10 \% \mathrm{w} / \mathrm{v})$ & $0.33 \pm 0.288$ & Weak \\
\hline Ethyl Acetate Fraction $(10 \% \mathrm{w} / \mathrm{v})$ & $9.66 \pm 0.577$ & Medium \\
\hline Methanol Fraction $(10 \% \mathrm{w} / \mathrm{v})$ & $0.00 \pm 0.00$ & - \\
\hline Negative Control $($ Ethanol $96 \%)$ & $0.00 \pm 0.00$ & - \\
\hline Positive Control $($ Vancomycin $30 \mu \mathrm{g})$ & $12.33 \pm 0.577$ & Strong \\
\hline
\end{tabular}

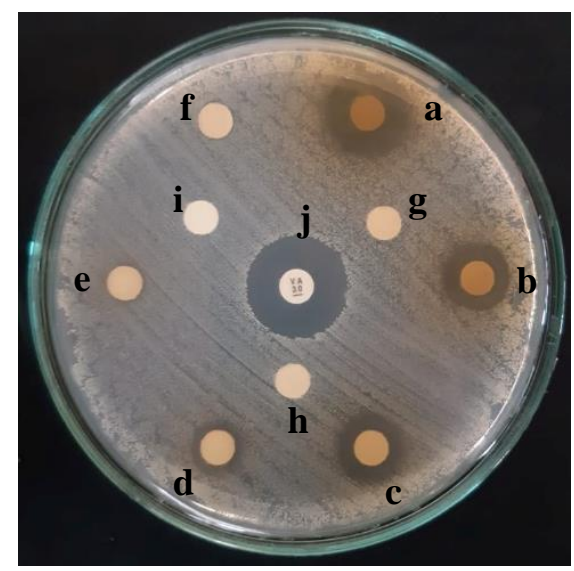

Figure 2. Testing the minimum inhibitory level of the ethyl acetate fraction with a concentration of: (a) $10 \%$, (b) $5 \%$, (c) $2.5 \%$, (d) $1.25 \%$, (e) $0.625 \%$, (f) $0.312 \%$, (g) $0.156 \%$, (h) $=0.078 \%$, (i) = negative control, $(\mathrm{j})=$ positive control. 
Table 2. Diameters of the inhibition zone of ethyl acetate fraction against Staphylococcus aureus.

\begin{tabular}{ccc}
\hline $\begin{array}{c}\text { Ethyl acetate fraction } \\
(\mathbf{\%} \mathbf{b} / \mathbf{v})\end{array}$ & $\begin{array}{c}\text { Inhibition zone } \\
(\mathbf{m m})\end{array}$ & Category \\
\hline 10 & $9.83 \pm 0.28$ & Medium \\
\hline 5 & $5.66 \pm 0.57$ & Medium \\
\hline 2.5 & $4.16 \pm 0.288$ & Weak \\
\hline 1.25 & $2.5 \pm 0.50$ & Weak \\
\hline 0.625 & $1.83 \pm 0.288$ & Weak \\
\hline 0.312 & $0.33 \pm 0.288$ & Weak \\
\hline 0.156 & $0.00 \pm 0.00$ & - \\
\hline 0.078 & $0.00 \pm 0.00$ & - \\
\hline Negative Control (Ethanol $96 \%)$ & $0.00 \pm 0.00$ & - \\
\hline Positive Control (Vancomycin $30 \mu \mathrm{g})$ & $12.33 \pm 0.577$ & Strong \\
\hline
\end{tabular}

Statistical analysis showed that the inhibition zone data at the lowest level of ethyl acetate fraction testing was not normally distributed and not homogeneous. It was based on the significance value of $<0.05$ in Kolmogorov-Smirnov and Lilliefors test and the significance value of $0.019<0.05$ in One Way ANOVA and LSD test. Therefore, further testing was done using the KruskalWallis test and the Mann-Whitney test. In the Kruskal-Wallis test, the result showed the significance of $0.002<0.05$. This shows that the treatment of the addition of the ethyl acetate fraction had a significant influence on the inhibition zones that emerged. Furthermore, the Mann-Whitney test showed that all concentration groups had significant differences. Therefore, it can be said that each concentration of ethyl acetate fraction- which consisted of $0.072 \%, 0.156 \%, 0.312 \%$,
$0.625 \%, 0.125 \%, 0.25 \%, 0.5 \%$ and $10 \% \mathrm{w} / \mathrm{v}-$ had different inhibitory zones. In addition, the Spearman correlation test showed the correlation coefficient value of 0.98 . The value falls between range 0.81-1.00 and therefore it can be concluded that there was a very strong positive correlation where the higher the concentration of ethyl acetate fraction was, the greater the inhibitory zone that appeared.

Furthermore, to separate the content of compounds in the ethyl acetate fraction, Thin Layer Chromatography (TLC) technique was used. TLC was done by bottling $5 \mu \mathrm{L}$ of ethyl acetate $10 \%$ onto the TLC plate. The results of the elution profile using mobile phase chloroform:ethyl acetate (2:8) and the stationary silica gel $\mathrm{F}_{254}$ phase can be seen in figure 3. By viewing through visible light and UV light, there were eight spots detected during the observation (Table 3 ).

Table 3. The Rf value of the ethyl acetate fraction detected on the Thin Layer Chromatogram using chloroform:ethyl acetate (2:8) as the mobile phase.

\begin{tabular}{ccccc}
\hline No. & Rf & Visible Light & UV 254 & UV 366 \\
\hline 1 & 0.00 & Brown & Brown & Black \\
\hline 2 & 0.21 & Brown & Brown & Black \\
\hline 3 & 0.44 & Green & Blue & Red Fluorescence \\
\hline 4 & 0.50 & - & - & Blue Fluorescence \\
\hline 5 & 0.69 & - & - & Blue Fluorescence \\
\hline 6 & 0.73 & Yellow & Yellow & Black \\
\hline 7 & 0.82 & Yellow & Yellow & Black \\
\hline 8 & 0.93 & Green & Yellow & Red Fluorescence \\
\hline
\end{tabular}




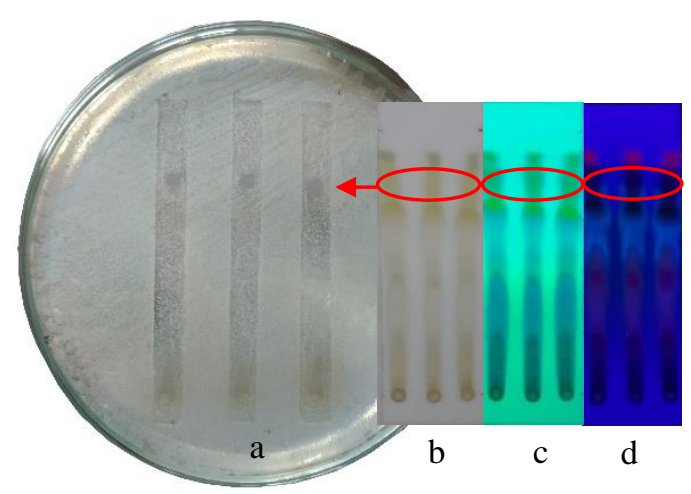

Figure 3. TLC-bioautography of ethyl acetate fraction, (a) TLC-bioautography of ethyl acetate fraction against Staphylococcus aureus by three replications; (b) TLC results viewed with visible light; (c) TLC results viewed with UV light $254 \mathrm{~nm}$, (d) TLC results viewed with UV light $366 \mathrm{~nm}$.

The bioautography test aims to determine which compound spots on TLC chromatograms have antibacterial activity. The active spots are marked by the formation of clear zones. The Rf value of the clear zone is calculated and matched to the Rf value of the chromatogram plate. TLC-Bioautographic test results of ethyl acetate fraction with three replications showed one active spot with an $\mathrm{Rf}$ value of 0.82 and had an inhibition zone diameter of $4.013 \pm 0.864 \mathrm{~mm}$ as presented in figure 3. The inhibition zone formed was caused by the presence of active compounds from the chromatogram spot which diffused into the media and caused inhibition of bacterial growth in the diffusion site of the active compound (Muthadi et al., 2012).

\section{CONCLUSION}

Ethyl acetate fraction is the most active fraction which inhibits the growth of Staphylococcus aureus bacteria and has the lowest levels of $0.312 \% \mathrm{w} / \mathrm{v}$ which still shows the inhibitory zone. Based on TLCBioautography testing using mobile phase of chloroform with ethyl acetate (2:8) and silica gel $\mathrm{F}_{254}$ as a stationary phase, ethyl acetate fraction has one active spot with an $\mathrm{Rf}$ value of 0.82 .

\section{ACKNOWLEDGMENT}

Thank you to The Ministry of Education and Culture for the master's thesis research grant for the 2019 budget year.

\section{REFERENCES}

Afifurrahman, Samadin, K.H., Aziz, S., 2014. Pola Kepekaan Bakteri Staphylococcus Aureus terhadap Antibiotik Vancomycin di RSUP Dr. Mohammad Hoesin Palembang. Majalah Kedokteran Sriwijaya, 46(4), 266-270.

Arum, Y., Supartono, Sudarmin, 2012. Isolasi dan Uji Daya Antimikroba Ekstrak Daun Kersen (Muntingia calabura). Jurnal MIPA, 35(2), 166-174.

Handoko, A.D., Setyawati, T., Asrinawati, A.N., 2019. Uji Efektivitas Antibakteri Ekstrak Daun Kersen (Muntigia calabura 1.) Terhadap Bakteri Escherichia coli. Medika Tadulako, 6(1), 9-21.

Lolongan, R.A., Waworuntu, O., Mintjelungan, C.N., 2016. Uji konsentrasi hambat minimum (KHM) ekstrak daun pacar air (Impatiens balsamina L.) terhadap pertumbuhan Streptococcus mutans. e-GIGI, 4(2), 242247.

Mahmudah, F.L., Atun, S., 2017. Uji Aktivitas dari Ekstrak Etanol (Boesenbergia pandurata) Terhadap Bakteri Streptococcus mutans. Jurnal Penelitian Saintek, 22(1), 59-66.

Manik, D.F., Hertiani, T., Anshory, H., 2014. Analisis Korelasi antara Kadar Flavonoid dengan Aktivitas Antibakteri Ekstrak Etanol dan Fraksi-fraksi Daun Kersen (Muntingia calabura L.) Terhadap Staphylococcus aureus. Khazanah, 6(2), $1-11$. 
Mulyani, Y., Sukandar, E.Y., 2011. Kajian aktivitas anti bakteri ekstrak etanol dan fraksi daun singawalang ( Petiveria alliaceae ) terhadap bakteri resisten. Majalah Farmasi Indonesia, 4(22), 293 299.

Muthadi, Ambarwati, R., Yuliani, R., 2012. Aktivitas Antibakteri Ekstrak Etanol dan Fraksi Kulit Batang Belimbing Wuluh (Averrhoa bilimbi Linn.) Terhadap Bakteri Klebsiella pneumoniae dan Staphylococcus epidermidis Berserta Bioautografinya. Biomedika, 4(2), 1-9.

Prastiwi, R., Siska, Marlita, N., 2017. Parameter Fisikokimia dan Analisis Kadar Allyl Disulfide dalam Ekstrak Etanol 70\% Bawang Putih (Allium sativum L.) dengan Perbandingan Daerah Tempat Tumbuh Parameter. Pharm Sci Res, 4(1), 32-47.

Puspitasari, A.D., Proyogo, L.S., 2016. Perbandingan Metode Ekstraksi Maserasi Dan Sokletasi Terhadap Kadar Flavonoid Total Ekstrak Etanol Daun Kersen (Muntingia Calabura). Jurnal Ilmu Farmasi \& Farmasi Klinik, 13(2), 16-23.

Rahmawati, N., Sudjarwo, E., Widodo, E., 2014. Uji aktivitas antibakteri ekstrak herbal terhadap bakteri Escherichia coli. Jurnal Ilmu-ilmu Peternakan, 24(3), 2431.

Sakr, A., Brégeon, F., Mège, J.L., Rolain, J.M., Blin, O., 2018. Staphylococcus aureus nasal colonization: An update on mechanisms, epidemiology, risk factors, and subsequent infections. Frontiers in Microbiology, 9(2419), 1-15.

Sulaiman, A.Y., Astuti, P., Shita, A.D.P., 2017. Uji Antibakteri Ekstrak Daun Kersen (Muntingia Calabura L.) Terhadap Koloni Streptococcus viridans. Indonesian Journal for Health Sciences, 1(2), 1-6.

Suryanto, E., 2012. Fitokimia Antioksidan. CV. Putra Media Nusantara, Surabaya.

Sylvester, W.S., Son, R., Lew, K.F., Rukayadi, Y., 2015. Antibacterial activity of java turmeric (Curcuma xanthorrhiza Roxb.) extract against Klebsiella pneumoniae isolated from several vegetables. International Food Research Journal, 22(5), 1770-1776.

Williamson, D.A., Lim, A., Thomas, M.G., Baker, M.G., Roberts, S.A., Fraser, J.D., Ritchie, S.R., 2013. Incidence, trends and demographics of Staphylococcus aureus infections in Auckland, New Zealand, 2001-2011. BMC Infectious Diseases, 13(1), 1-9.

Zebua, R.D., Syawal, H., Lukistyowati, I., 2019. Pemanfaatan Ekstrak Daun Kersen (Muntingia calabura L) untuk Menghambat Pertumbuhan Bakteri Edwardsiella tarda. Jurnal Ruaya, 7(2), $11-20$. 